\title{
Text-type, context and demonstrative choice in written Dutch: Some experimental data*
}

\author{
R.S. KIRSNER, V.J. VAN HEUVEN and J.F.M. VERMEULEN
}

Abstract

Fifty Dutch native speakers were asked to identify the original demonstrative in sentences in which all adjectival occurrences of 'deze' 'this/these' and 'die' 'that/those' had been uniformly replaced with the string '***'. First, the results suggest that native speakers know which genres of written Dutch have the highest frequency of each demonstrative. Second, on average, only the identification of 'deze' improved when the sentences were presented in their original context - a result which accords with earlier studies (Kirsner, 1979; Kirsner and van Heuven, 1980, 1986) showing that 'deze' 'retrieves' previously mentioned entities over longer referential distances (cf. Givón, 1983) than 'die'. The results for the individual test-sentences show that other factors contributing to an increase of correct identification of 'deze' in context are (a) information in the context about either the referent or the speaker's attitude towards it, and (b) information within the test-sentences themselves provided by verb-tense and lexicon. That this particular cluster of factors should influence demonstrative choice lends credence to the view of 'deze' as instructing the addressee more forcefully than 'die' to seek out and attend to the noun's referent.

\section{Introduction}

Demonstratives are a favorite topic of abstract theoretical discussion among both linguists and philosophers: cf. Roman Jakobson (1971) and Buchler (1940: 107-111) on Charles Sanders Peirce's categorization of demonstratives as 'indices' rather than 'icons' or 'symbols.' However, with the notable ex- 
ceptions of Jarvella and Klein (1982) and Weissenborn and Klein (1982), there has been little empirical examination of the actual use by native speakers of specific demonstratives in individual languages.

Such empirical work is the concern of the present exploratory study. Its purpose is to delineate some of the factors which lead native speakers of Dutch to prefer one type of demonstrative adjective to the other in sentences taken from various written Dutch texts. More specifically, it investigates how well native speakers are able to identify which demonstrative adjective deze 'this/these' or die 'that/those' (including also their respective allomorphs dit and dat) - had been present in sentences in which all adjectival uses of both forms are replaced by a string of three asterisks: ***. All that the native speakers were told was that the asterisks marked the position of a demonstrative adjective. The questions investigated are: (a) how well and (b) on what bases can native speakers figure out which demonstrative it was?

These questions are interesting precisely because so little is known about how Dutch speakers actually go about choosing a demonstrative in a particular written context. Earlier studies (Kirsner, 1979, 1985; Kirsner and van Heuven, $1980,1986)$ have been purely observational in the sense of Miller (1975: 13), correlating the occurrence of deze versus die in written texts with such factors as (i) position of the demonstrative in the sentence, (ii) whether or not the referent of the noun is human or non-human, (iii) 'new' or 'old' in the discourse and, in the last case, (iv) the magnitude of the referential distance (cf. Givón, 1983). However, there has been no experimental work to show which of these correlations (if any) reveal what native speakers themselves are doing when they select deze or die over its theoretical alternative. One aim of our research was to determine, by means of a questionnaire experiment, whether, and in what way, such correlations might be reflected in the behavior of experimental subjects confronting an identification task.

\section{Two influences on demonstrative choice}

One factor which we would surely expect to influence the native speakers is context. We may anticipate that if test-sentences were presented first in isolation and then in the original paragraphs from which they were extracted, the extra information contained in the latter would - in, as yet, poorly understood ways - make the choice of demonstrative less arbitrary and would thereby increase the accuracy with which the demonstratives are 
identified. Ideally, a comparison of subjects' responses to isolated sentences and to contexted sentences would permit us to understand in more detail what kind of contextual information interacts with what kind of intrasentential information to help to determine which demonstrative is more appropriate. Ultimately, the appeal to the general term 'context' could be replaced by a listing of these more specific factors.

A second potential influence on demonstrative selection is 'genre', here more accurately described as 'text-type', as will be explained below. Kirsner (1979: 368-369) notes that the relative frequency of deze rather than die correlates with the choice of written versus spoken language and, in the former, the degree of difficulty and/or formality of the text. Two questions raised by these findings are whether the native speakers themselves have internalized such correlations and, if so, to what extent?

\section{Design of the questionnaire}

To make the sample as representative of written Dutch as possible, we took as the source of data two machine-readable collections of text fragments originally compiled for word-frequency studies. The first, described in detail in Uit den Bogaart (1975), was designed to give as good a picture as possible of 'the Dutch language as a whole' and totals 600,000 word tokens broken down into five subcorpora of equal size: novels, daily newspapers, family magazines, weekly magazines of opinion and analysis, and popular science. The second collection, our sixth subcorpus, is comprehensively discussed in Renkema (1981) and was originally compiled for a stylistic comparison of government language with subcorpora 2, 4 and 5. It totals 48,000 words and consists of uniform fragments four sentences long extracted from official Dutch government publications and correspondence. Given that newspapers and family magazines actually contain many different kinds of genres in the technical sense (e.g. informative pieces on current events, editorials, short fiction, advice to the lovelorn, information on health and nutrition, etc.), it is perhaps more accurate to describe these subcorpora as simply representing different text-types, as we shall do henceforth."

In order to observe the impact of text-type upon demonstrative choice, it was decided to present the subjects with a neutral stimulus: equal numbers of original instances of deze and die (i.e. 50\% of each) and equal numbers of sentences from each subcorpus. Furthermore, although it was impossible to 
control for all variables which might correlate with text-type, we did decide to do this for the most easily quantified one: sentence-length. Finally, in view of the importance of referential distance in the earlier correlational studies cited in the introduction, we limited our sample of demonstrative-bearing NPs to those with 'old' referents.

Accordingly, from each of the six subcorpora, eight sentences containing one demonstrative adjective were selected at random such that the following criteria were met:

(a) For each subcorpus, an equal number of occurrences of the two demonstrative types, deze and die, were chosen.

(b) For each subcorpus, there were two instances of each type of demonstrative in sentences of the following lengths: 13 words, 15 words, 17 words, 19 words. These particular lengths were selected so that we could find naturally occurring examples of all the sentence lengths in each of the text types contained in the Uit den Boogaart and the Renkema collection of text fragments.

(c) The noun phrase containing the demonstrative adjective did not introduce a new referent into the discourse but 'retrieved' one mentioned earlier.

(d) There was sufficient context in the corpus to contain that mention of the referent which was immediately prior to the mention with the noun phrase containing the demonstrative adjective.

This yielded 6 (text types) $\times 2$ (demonstrative types) $\times 2$ (instances of demonstrative type) $\times 4$ (sentence lengths) $=96$ test sentences and their associated contexts (spanning maximally 5 sentence boundaries).

Two versions of the test sentences were prepared: one containing the complete text fragments described above, and one containing only the final sentences with the crucial demonstrative adjective. In all cases, this demonstrative was replaced by a sequence of three asterisks $(* * *)$, including instances of original deze, so that the size of the gap would not betray the identity of the deleted demonstrative.

Sentences and paragraphs were subsequently typed out in two separate randomized blocks, so that there was one listing of isolated sentences in one random order, and a second listing of contexted sentences in a second random order. Subjects were instructed to attempt to determine what the deleted demonstrative 'must have been' (i.e. what the $* * *$ stood for) and were given a forced choice between deze (and its allomorph dit) and die (and its allomorph dat). One half of the respondents received both the isolated sentences 
and the paragraphs in their reversed order so as to counterbalance potential order and learning effects. In each of the two versions of the questionnaire, subjects were given the 96 isolated sentences prior to the block of 96 paragraphs. Subjects were instructed not to look back or change earlier answers.

The questionnaires were administered to 50 undergraduate students (male and female in roughly equal proportions) enrolled in an introductory linguistics class at Leyden University. All were native speakers of Dutch. Respondents participated on a voluntary basis and received some remuneration for their efforts.

\section{Results}

The responses of the 50 subjects were treated as a collective measure of demonstrative identifiability, as follows: initially, two groups of 25 subjects (one for each of the two versions of the questionnaire) were asked to identify the missing demonstrative in two groups of 96 sentences (one group in isolation, then another group in paragraphs [context]). Accordingly, we began with 25 judgements on each of 384 sentences. An initial measure of the identifiability of the demonstratives was then defined as the percentage of correct identifications in the 25 judgements. Defined in this manner, the mean percentage of correct identifications for all demonstratives in all sentences was $65.9 \%$ which, though far from perfect, is significantly above the chance $(50 \%)$ level, $\chi^{2}(d f=1)=968(p<.001){ }^{2}$ It was next determined that the effect upon this percentage of the two different orders in which the sentences had been presented was not significant, $t(382)=-1.32(p=.18$, two-tailed).Percent correct was henceforth expressed relative to 50 responses per case, across order of presentation.

\subsection{Text-type}

Overall, (i.e. when one combines the results for the 96 isolated sentences and the 96 contexted sentences), neither demonstrative was identified correctly significantly more often than the other; the percent correct for deze was 66.1 , and for die $65.7, t(190)=0.14(p>.8)$. However, when one analyzes these results per subcorpus, the trends emerge which are shown in Figure 1. As will be discussed in more detail in Section 5.1, Table 1, the order of text- 


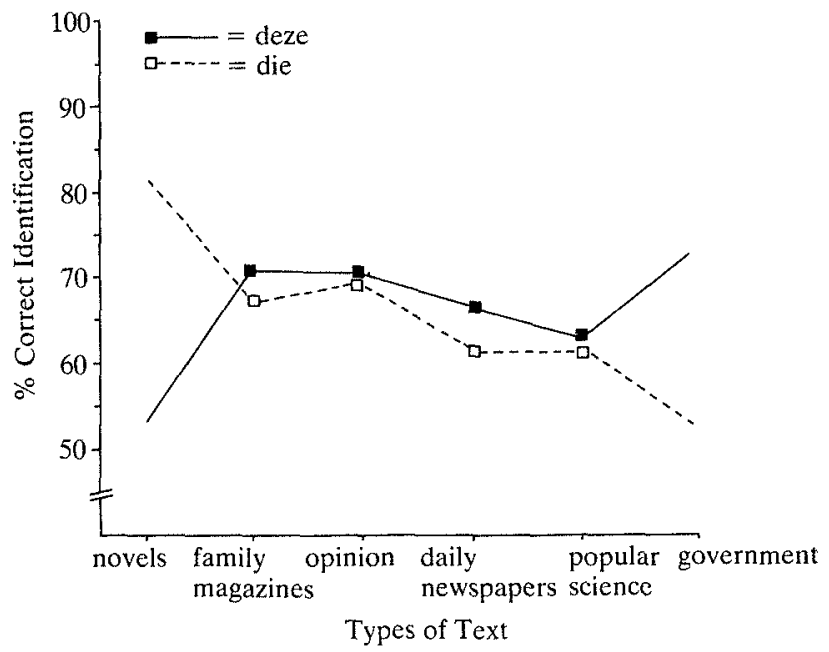

Figure 1. The influence of demonstrative-type and text-type on the percentage of correct identifications of the demonstrative adjective

types along the $X$-axis (from left to right) reflects the relative frequency of deze versus die in sentences containing one demonstrative adjective in a 4200 -sentence sample of sentences from the six subcorpora in question.

Note that in novels, deze is identified at a very bad, near chance, level; die is identified very well, about $80 \%$ correct. This difference is shown by a $t$-test (two-tailed) to be significant at the .01 level. On the other hand, in government language, die is identified badly (at 52.8\%; chance level) while deze is identified well (at $73 \%$ ), with again the difference in percentage correct being significant at the .01 level. Observe further that in the texttypes in the middle, both demonstratives do equally well and there is no significant difference in percentage of correct identifications. For the sake of brevity, we shall call this reversal of percentage correct for deze and die in novels and government language the 'text effect'. An explanation will be offered in Section 5.1 below.

\subsection{Context}

As one would. expect, the percentage of correct identifications is higher for demonstratives in the contexted sentences $(67.6 \%)$ than in the isolated sentences $(64.1 \%)$. This overall difference, however, is not statistically significant, 
$t(190)=-1.21(p>0.1$, one-tailed $)$. However, if one separates the figures for the two demonstrative types, a striking asymmetry is observed. Consider Figure 2:

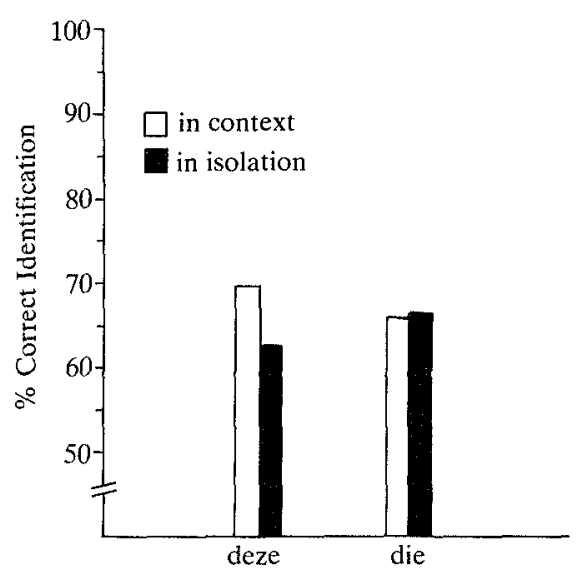

Type of Demonstratıve

Figure 2. The influence of demonstrative-type on the context effect

The fraction of correct identification for deze is $69.7 \%$ in context and $62.5 \%$ in isolation, which is a significant difference, $t(94)=-2.01(p<.03$, one-tailed). In contrast, the fraction of correct identifications for die is $65.6 \%$ in context and $65.7 \%$ in isolation, which is not a significant difference, $t(94)=-0.02(p=.98)$. It would appear, then, that adding context improves the identifiability of deze but not of die. For the sake of brevity, the trend shown in Figure 2 will be termed the 'context effect'. Possible explanations for it will be taken up in Section 5.2.

\subsection{The combined effect}

The context effect is not homogeneous but varies according to subcorpus. As shown in Figure 3, adding context improves the identifiability of deze very significantly in the opinion and analysis sample $(p<.005)$, and almost significantly in the popular science sample $(p<.1)$, as measured by the $t$-test (one-tailed). 


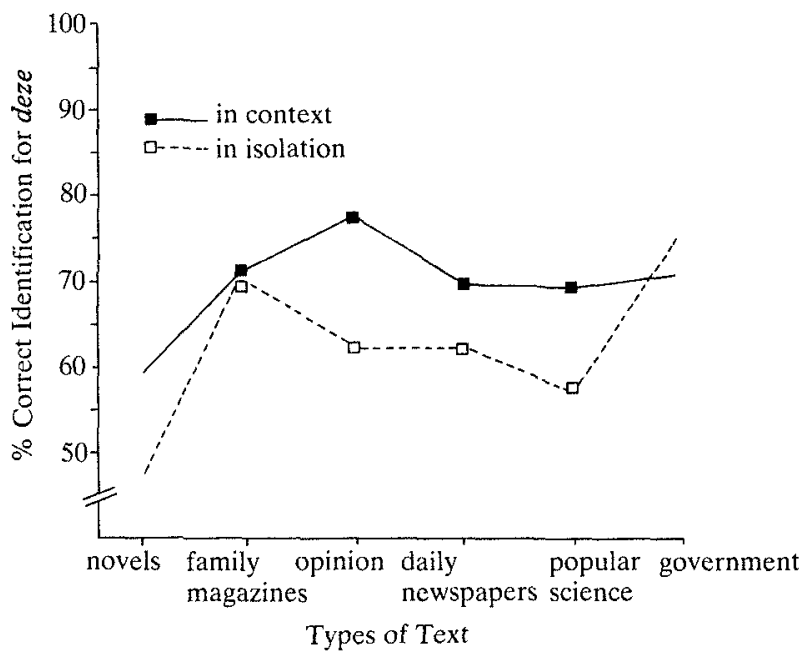

Figure 3. The context effect for 'deze' according to text-type

Adding context does not significantly improve the identifiability of die in any subcorpus, as shown in Figure 4.

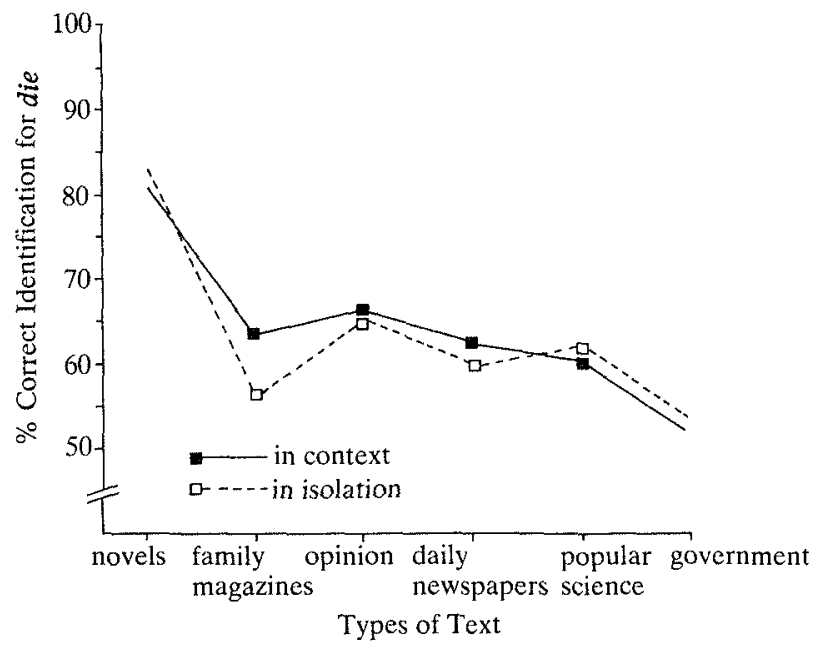

Figure 4. The context effect for 'die' according to text-type

In Section 5.2.1. we shall offer a partial explanation for the occurrence of significant and near-significant context effects for deze in the opinion and analysis and the popular science subcorpora, but nowhere else. 


\section{Discussion}

\subsection{Linguistic expectancy and the text effect}

Evidence continues to accumulate supporting the view that native speakers are aware of the relative frequency of different grammatical forms in language use. Thus, frequently used words are recognized better than uncommon words; when a low-frequency word is not correctly recognized, a higher-frequency word is responded with instead, but not vice versa (cf. e.g. Grosjean, 1980, and the references given there). Similarly, van Heuven (1978: 184185) demonstrates that the interpretation which experimental subjects give ambiguous verb endings in Dutch can be predicted from the text frequency of these endings in their different grammatical functions. It may be hypothesized that the subjects have learned through long exposure how often a particular form will have a particular function, and that they interpret unclear cases in the light of what they have come to expect.

We would suggest here that the explanation for (i) the abnormally low percentage of correct identifications of die in government language and of deze in novels and (ii) the abnormally high percentage of correct identifications of deze in government language and of die in novels is similarly due to our subjects' internalized knowledge of the relative frequency of the two types of demonstratives in different kinds of texts (which can often be distinguished simply on the basis of lexical content). Consider the data in Table 1, adapted from Kirsner and van Heuven (1986).

Table 1. Relative frequency of 'deze' and 'die' in sentences containing one demonstrative adjective in a sample of such sentences in the Uit den Boogaart 1975 and Renkema 1981 collections. Sentences sampled were those for which the $N P$ containing the demonstrative could be classified unambiguously for both grammatical function (subject vs. object) and clause environment (main clause vs. elsewhere)

\begin{tabular}{lccc}
\hline & deze & die & deze \\
\hline & $(\mathrm{N})$ & $(\mathrm{N})$ & $(\%)$ \\
Novels & 135 & 358 & 27.4 \\
Family & 365 & 381 & 48.9 \\
Opinion & 493 & 366 & 57.4 \\
Newsp. & 518 & 216 & 70.6 \\
Pop. Sci. & 669 & 254 & 72.5 \\
Govt. & 418 & 75 & 84.8 \\
Total & 2598 & 1650 & \\
\hline
\end{tabular}


We suggest that Dutch speakers 'know' that deze is relatively infrequent in novels and frequent in complicated prose, such as government language, and that the reverse holds for die. Accordingly, it makes sense that, when given an artificially designed 50-50 sample, as was done in the questionnaire, speakers underestimate the number of dezes in sentences from novels and underestimate the number of dies in sentences from government language. When the stimuli are ambiguous, the subjects will react according to their own prior experience, experience which is summarized in Table 1 . This view receives strong support from the high correlation $(r=89, p<.01, N=6)$ which was found between (a) the average number per subcorpus of dezeresponses on the questionnaire and (b) the percent of deze occurrences as a function of text-type, shown in Table 1 . This correlation remains both high and statistically significant whether one combines the results for the isolated and the contexted sentences, as we have done, or splits them. Note that for the sentences presented in isolation, the degree of correlation is slightly lower and less significant: $r=.80, p<.03, N=6$; for the sentences presented in context, the result is slightly higher and more significant: $r=.95, p<.003$, $N=6$.

\subsection{The context effect}

\subsubsection{Referential distance}

In a number of studies (Kirsner, 1979, 1987; Kirsner and van Heuven, 1980, 1986), it has been shown that die tends to be used to repeat reference to an entity mentioned earlier within the very same sentence that contains the demonstrative-bearing NP, while deze tends to be used to 'retrieve' referents mentioned only in earlier sentences. ${ }^{3}$ Following Givón 1983), we shall call the distance from the demonstrative-bearing NP to the first prior mention of the referent the referential distance (henceforth: RD). We shall measure $\mathrm{RD}$ in terms of the number of orthographic sentence boundaries between the demonstrative-bearing NP and this first prior mention. Accordingly, we may restate the result of earlier studies by saying that deze tends to be associated with $\mathrm{RD} \geqslant 1$ and die tends to be associated with $\mathrm{RD}=0$.

As an illustration, Kirsner and van Heuven (1986), Table 6, presents data on 526 sentences (containing only one demonstrative adjective) from 5 separate text samples. Of these, 266 sentences contain deze and 260 die. Of the NPs with deze, only 39 , or $15 \%$, have RD $=0$. Of the NPs with die, fully 
104 , or $40 \%$, have $\mathrm{RD}=0$. More specifically the mean $\mathrm{RD}$ associated with deze is 1.045 sentence-boundaries, which is $35 \%$ greater than the mean RD of die, 0.7731 sentence-boundaries. Both the parametric $t$-test and the nonparametric Mann-Whitney $U$ test indicate that the difference between the RDs associated with deze and the RDs associated with die is highly significant, $p<.001$. In other words, the difference between the two populations of RDs could arise by pure chance less than one time out of a thousand.

Data such as these suggest that if one removed prior sentences from the context (as was done in the first part of the questionnaire), one would tend to remove information justifying the choice of deze more frequently than information justifying the choice of die. In consequence, one might well expect that original dezes would be identified less well than original dies if both were replaced by $* * *$ in the test sentences. Furthermore, since die is used more often for intrasentential retrieval of the referent and deze more often for intersentential retrieval, we would expect identification of deze to be much more sensitive to information in the prior context than identification of die. Accordingly, the difference in referential distance associated with deze and die suggests an immediate explanation for the context effect illustrated in Figure 2. With this concept, we can understand items (a) and (b) but not (c) of the following: (a) why the level of die-identifications remains constant, (b) why deze is identified less well in isolation than die, (c) why deze is identified better in context than die is. What the concept of referent distance still does not seem to explain is why die and deze do not do equally well when the full context is provided. We shall see below, however, that this is not the case; i.e. that the difference in RD between deze and die can also explain why, in full context, die still does not do as well as deze.

Although the difference between the average RD shown by deze and by die in the questionnaire sentences is not as pronounced as in the larger sample discussed above, it is still appreciable. For the 48 test-sentences containing deze, the mean RD is 1.29 sentence boundaries; for the 48 test-sentences containing die, the mean RD is 1.08 sentence boundaries, about $17 \%$ less. The difference is statistically significant by a Mann-Whitney $\mathrm{U}$ test: $p<.05$, one-tailed. If we now examine the RD-values for deze and die in the test-sentences from each of the subcorpora, we will observe an interesting connection with the context effect per subcorpus illustrated in Figures 3 and 4 seen previously.

Figure 5, following, gives the mean referential distance for deze and die for each text type; the ratios may be compared with the size of the context effect for deze shown in Figure 3 above: 


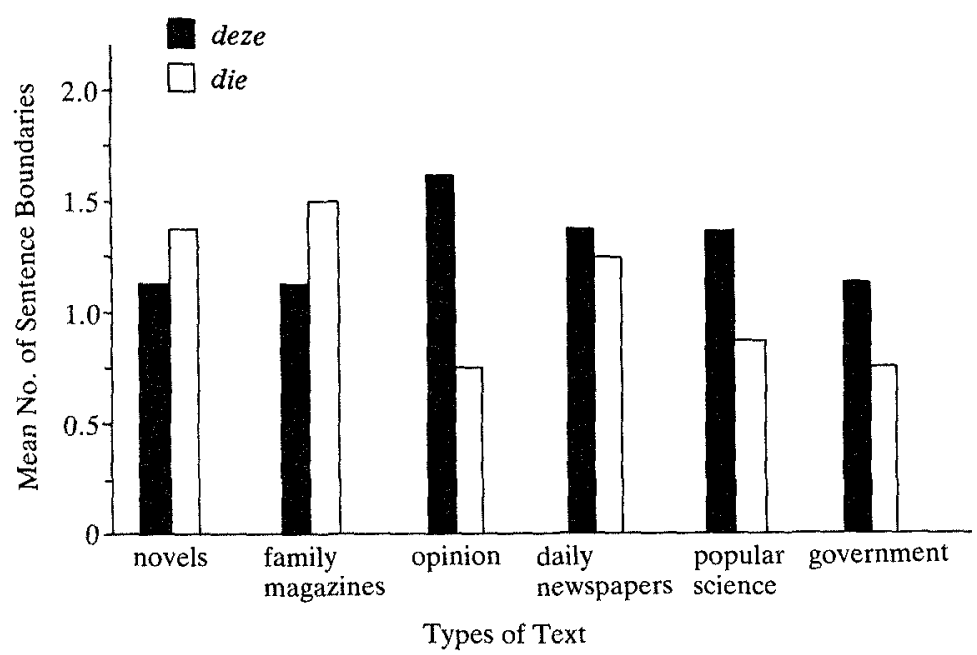

Figure 5. Mean referential distances for 'deze' and 'die' in the questionnaire sample of text-types

Table 2 below indicates for each corpus: the mean RD in sentence boundaries for the eight test sentences containing deze, the mean $\mathrm{RD}$ for the eight test sentences containing die, the significance of their difference (Mann-Whitney test), the quotient of the mean RD for deze divided by the mean RD for die, and, finally, whether there was a significant context effect for deze in the corpus, as indicated by the responses of the 50 subjects:

Table 2. Strength of context effect as a function of the ratio of the mean referential distance for 'deze' and 'die'

\begin{tabular}{llllll}
\hline Corpus & $\begin{array}{l}\text { RD } \\
\text { deze }\end{array}$ & $\begin{array}{l}\text { RD } \\
\text { die }\end{array}$ & Significance & Ratio & $\begin{array}{l}\text { Context } \\
\text { Effect }\end{array}$ \\
\hline opinion & 1.63 & 0.75 & $p<.02$ & 2.173 & $p<.005$ \\
pop. sci. & 1.38 & 0.88 & $p<.03$ & 1.568 & $p<0.1$ \\
govt. & 1.13 & 0.75 & $p<.05$ & 1.507 & ns \\
dailies & 1.38 & 1.25 & ns & 1.104 & ns \\
novels & 1.13 & 1.38 & ns & 0.818 & ns \\
fam. mgs. & 1.13 & 1.50 & ns & 0.753 & ns \\
\hline
\end{tabular}


Note that the difference in RD is statistically significant in three corpora magazines of opinion and analysis, popular science, and government language - and that this group contains the one corpus - opinion and analysis which shows a statistically significant context effect. Observe furthermore that there is no case of a significant context effect without a significant difference in the RD for deze and die. (That would of course instantly invalidate the hypothesis that the difference in referential distance between deze and die somehow underlies the context effect.) It thus appears that the existence of a statistically significant difference between the referential distances associated with deze and die is a necessary but not a sufficient condition for the context effect. One might speculate from Table 2 that the difference must not only be statistically significant but must also reach some threshold magnitude, perhaps a quotient of the RD for deze and die of about 2.00. Other factors than RD must also be involved in demonstrative choice. Some of these will be taken up in Section 5.2.2.

A less static and quite different view of the context effect is provided by examining in detail the difference in percentage of correct identifications achieved by each test sentence individually, both in context and in isolation, so that each sentence is used as its own control. The overall result is the same as was discussed in Section 3.2: the mean difference for sentences containing deze is +7.17 percentage points and is -.08 percentage points for sentences containing die : $t(94)=2.12(p<.04$, two-tailed). In other words, when one compares the percentage of the fifty subjects identifying the demonstrative correctly when the sentence is presented in context and when the same sentence is presented in isolation, there is a difference of 7 percentage points for deze and effectively no difference for die. However, it is not at all the case that each sentence containing deze does better in context than in isolation or that all sentences containing die do either slightly worse in context than in isolation or stay the same. As shown in Table 3, there are an appreciable number of instances in which addition of context leads to an increase in incorrect identifications on both sides: e.g. cases of original die misidentified in the contexted sentences as deze and cases of original deze misidentified in the contexted sentences as die. Such results suggest that the process (or processes) by which subjects identified the demonstrative was less cut-and-dried, more 'dynamic' than might first appear, and raises the question of 'Why?', Why should there be such 'confusions', especially when information is being provided in the context which should, if anything, clarify matters? Consider the data in Table 3. 
Table 3. Effect of adding context on demonstrative identification for the 96 test sentences

\begin{tabular}{lcr}
\hline & \multicolumn{2}{c}{ Original demonstrative in } \\
sentence: & \\
$\begin{array}{l}\text { Percentage of correct } \\
\text { identifications }\end{array}$ & deze & die \\
\hline Increases in context: & $30(62.5 \%)$ & $17(35.4 \%)$ \\
Remains unchanged: & $2(4.2 \%)$ & $3(6.3 \%)$ \\
Decreases in context: & $\frac{16(33.3 \%)}{48(100 \%)}$ & $\frac{28(58.3 \%)}{48(100 \%)}$ \\
& 48
\end{tabular}

On balance, the presentation of sentences in context leads to the net increase of correct deze identifications in $62.5 \%-33.3 \%$, or $29.2 \%$ of the test sentences, but a net decrease of correct die identifications in $22.9 \%$ of the test sentences (35.4\%-58.3\%). Apparently, addition of context made the subjects choose deze in more of the test sentences, whether this was appropriate or not.

At this point, it might seem that the identity of the original demonstrative is immaterial and that (as shown in Table 3) addition of context brings about not only a recategorization of $62.5 \%$ of the original deze-sentences as (correctly) containing deze but also a recategorization of $58.3 \%$ of the original die-sentences as also (but incorrectly) containing deze; the percentages are, after all, quite comparable. This view is incorrect; the identity of the original demonstrative is important. The only reason we have not seen it yet is that we have been examining only the fraction of test-sentences showing a switch - any switch - between the percentage of correct identifications in context and the percentage of correct identifications in isolation. We have been considering only the presence vs. the absence of a switch, and not its size. The picture is quite different if we look at the average magnitude of the switch, shown in Table 4.

As is shown in Table 4, the magnitude of the increase in identification as deze or die is always greater by nearly 7 percentage points for the correct original demonstrative. But this still leaves us with the question of the errors. Why are they made at all?

One obvious possibility suggested by the difference in referent distance between deze and die is that those demonstratives get misidentified which behave atypically; e.g. that if a deze is restored less well in context than in isolation, it is because it looks in context more like a prototypical die than 
Table 4. The effect of adding context

Average percentage increase in (correct or incorrect) identification of demonstrative as:

\begin{tabular}{lll} 
Sentence actually contains: & deze & die \\
\hline deze & $+16.87(\mathrm{~N}=30)$ & $+10.13(\mathrm{~N}=16)$ \\
& $($ correct $)$ & $($ incorrect $)$ \\
die & $+10.64(\mathrm{~N}=28)$ & $+17.29(\mathrm{~N}=17)$ \\
& (incorrect) & (correct)
\end{tabular}

prototypical deze, and that the reverse holds for misidentified dies. In other words, if deze typically 'retrieves' referents in texts over a greater number of sentence boundaries than die, then (a) dezes which do worse in context should exhibit a smaller, more die-like $\mathrm{RD}$, and (b) dies which do worse in context should exhibit a larger, more deze-like $\mathrm{RD}$. The raw data from the questionnaire are given in Table 5.

Table 5. Direction of context effect as a function of demonstrative and retrieval distance in the 96 test sentences

\begin{tabular}{lccc}
\hline & \multicolumn{4}{c}{$\begin{array}{c}\text { Referent distance } \\
\text { (in sentence-boundaries) }\end{array}$} \\
& 0 & 1 & 2 \\
\hline deze & 1 & 21 & 8 \\
Improves in context: & 0 & 12 & 4 \\
Worsens in context: & 0 & 1 & 1 \\
Stays the same: & 1 & 34 & $13=48$ in all. \\
Total: & & & 2 \\
die & 4 & 11 & 6 \\
Improves in context: & 3 & 2 & 1 \\
Worsens in context: & 0 & 32 & $9=48$ in all. \\
Stays the same: & 7 & & \\
Total: & & 19 &
\end{tabular}

Observe that the percentage of die-sentences improving in context drops from $4 / 7(57 \%)$ to $11 / 32(34 \%)$ to $2 / 9(22 \%)$ as the $\mathrm{RD}$ increases to 1 and 2 or more sentence-boundaries, but that no real trend is seen for the dezesentences: $1 / 1(100 \%) ; 21 / 34(62 \%) ; 8 / 13(62 \%)$. There is, then, some support for the hypothesis that the dies which are misidentified in context are 
those with longer (more deze-like) RDs. The skew in improvement/ deterioration in context between deze and die $(21 / 12$ versus $11 / 19)$ is clearly significant for $\mathrm{RD}=1: \chi^{2}(d f=1)=4.58(p<.05)$. However, it cannot be shown that this skew is slighter for $R D=0$, or larger for $R D \geqslant 2$ because of the extremely small number of observations in these subtables. For the sake of completeness, we now give in Table 6 the magnitude of the difference between the percentage of correct identifications in context and in isolation for each demonstrative type and RD.

Table 6. Effect of adding context on percentage of correctly identified demonstratives, broken down by demonstrative type and referent distance (see text)

\begin{tabular}{llll}
\hline $\begin{array}{l}\text { Number of } \\
\begin{array}{l}\text { Sentence } \\
\text { Boundaries }\end{array}\end{array}$ & \multicolumn{2}{c}{$\begin{array}{c}\text { Difference in Percentage } \\
\text { of Correct Identifications } \\
\text { in Context vs. Isolation } \\
\text { deze }\end{array}$} & $\begin{array}{l}\text { Significance } \\
\text { by } t \text {-test } \\
\text { (two-tailed) }\end{array}$ \\
\hline 0 & +6.00 & +4.00 \\
$(\mathrm{~N}=1)$ & $(\mathrm{N}=7)$ & $p>.8$ \\
1 & +8.41 & -1.13 & \\
& $(\mathrm{~N}=34)$ & $(\mathrm{N}=32)$ & $p<.04$ \\
& +4.00 & +0.44 & \\
& $(\mathrm{~N}=13)$ & $(\mathrm{N}=9)$ & $p>.5$ \\
\hline
\end{tabular}

Observe that the difference between these differences is statistically significant only in the sample with $\mathrm{RD}=1$. We find that the mean 'improvement' in context is +8.41 percentage points for the sentences with original deze and -1.13 percentage points for the sentences with original die. Since die tends to be used for intrasentential retrieval and deze for extrasentential retrieval, it makes sense that when the referent is last mentioned in the immediately preceding sentence, identification of deze would improve in context while identification of die would deteriorate. At least some of the dies are misidentified as deze because the referent distance with which the subjects are confronted is more characteristic of a typical deze than a typical die.

We may thus conclude that the referent distance concept can indeed help to explain each of the three points mentioned earlier: we can now understand not only (a) why the gross level of die-identifications would tend to remain constant in context and in isolation, and (b) why deze is identified better in context than die, but also (c) why the identification of die does not improve in context. At least a partial answer is that when the context shows that a 
prior sentence contains a first mention of a referent repeated in the test sentence, subjects choose that demonstrative - deze - which is more closely associated with 'long distance' retrieval.

\subsubsection{Information about the referent}

In the preceding section we attempted to explain the context effect by focusing on a single aspect of the semantic contrast between deze and die: their favoring of different referential distances. A second factor contributing to the effect of context on demonstrative choice is the degree of information which the context provides about the referent of the noun. In order to appreciate this factor, however, we must briefly confront the issue of demonstrative meaning.

In Kirsner (1979, to appear) and Kirsner and van Heuven (1980, 1986: Section 7.2), it is suggested that both deze and die are fundamentally concerned not with spatio-temporal distance (as is traditionally thought) but rather the degree of attention which the addressee is instructed to give to the referent of the noun. Deze is hypothesized to signal a very forceful instruction to the hearer to seek out and attend to the noun's referent, while die is claimed to signal a weaker one. Furthermore, a forceful instruction to attend is held to be communicatively most useful either (i) when the referent-tracking task facing the addressee is more difficult than it might otherwise be, or (ii) when the speaker regards the referent as particularly noteworthy. The larger RD associated with deze reflects both of these aspects, in that (a) it is presumably harder for the hearer to 'retrieve' a referent over longer stretches of discourse than over shorter ones, and (b) more noteworthy entities will tend to be talked about longer: at least longer than one sentence.

However, other factors than brute distance also influence choice in a way which the 'instructional' view of demonstratives clarifies. Kirsner (1985) discusses a minimal pair of examples in which both deze and die are used to 'retrieve' a referent across the very same referential distance: a single sentence boundary also serving as a paragraph boundary. The motivation for choosing deze in one instance and die in another appears to be whether the referent was to continue to be the center of attention in the discourse (in which case deze - 'maximum attention!' - was used), or merely a transitory bridge to some other topic (in which case die, centering less attention on that particular noun's referent, was selected). Similarly, Kirsner (1987) discusses the competition between deze and die at RDs of 0 and 1 sentence boundaries in Nuchelmans (1969) in the special case when both the prior mention and the 
second mention of the referent are effected with a 'bare' noun, unmodified by any adjective or prepositional phrase. In intrasentential retrieval $(\mathrm{RD}=0)$, deze is used to re-mention referents which are of central importance in the text (and which occur elsewhere in the paragraph in question) while die is used for more peripheral and ephemeral entities. At referent distances of 1 , die is used to simply repeat the referent, while deze is used when the referent undergoes 'development' of some kind between the mentions, e.g. when the referent is either described in detail or illustrated in some way; i.e. is explicitly made more salient by the speaker.

Close examination of the questionnaire sentences uncovers similar phenomena. For instance, when the context indicates that a particular referent has been considered in detail, it is reasonable to conclude that it is relatively important and hence merits greater attention (cued with deze) rather than less attention. One example is the following:

Het heeft na Mendelejev nog ongeveer een halve eeuw geduurd voordat *** vraag werd beantwoord.

'After Mendeleyev, it took about another half a century before *** question was answered.'

When this sentence was presented in isolation, exactly half (50\%) of the 50 subjects identified the missing demonstrative as deze and half as die. Now examine the entire passage:

Maar er zijn nog meer stoffen die geen elementen zijn. Hoe kregen de elementen het voor elkaar deze stoffen op te bouwen? Anders gezegd, en algemener: als twee stoffen een verbinding met elkaar aangaan en een derde stof opleveren, wat gebeurt er dan eigenlijk? Het heeft na Mendelejev nog ongeveer een halve eeuw geduurd voordat $* * *$ vraag werd beantwoord.

'But there are many more substances which are not elements. How were the elements able to construct these substances? Stated differently and more generally: if two substances form a compound with one another and produce a third substance, what really happens? After Mendeleyev, it took about another half a century before *** question was answered.'

In context, where the question is formulated successively in two different ways, $72 \%$ of the 50 subjects correctly identified the missing demonstrative with the noun vraag as deze. (Hence, the difference between the percentage of correct identifications in context and percentage of correct identifi- 
cations in isolation is $72 \%-50 \%=+22$ percentage points, in this particular example.)

Context can also provide information about the speaker's attitude toward the referent. One instance which parallels the case discussed in Kirsner (1985), where deze is used to maintain attention on a referent and die to decrease attention, preparatory to turning away to something else, is the following:

Op ${ }^{* * *}$ koers hebben we naar mijn mening al veel te lang gevaren.

'In my opinion we have followed ** course much too long already.'

When this sentence was presented in isolation, $54 \%$ of the subjects identified the missing demonstrative as deze. However, if it is reasonable that the speaker would tend to use deze to refer to entities meriting continued attention, and die for entities not meriting it, any cue that further attention is not deserved would favor the selection of die. Examine now the entire passage and pay special attention to the adjective absurd:

Nol de Jong, secretaris van de ondernemingsraad, zei kernachtig: "Er is een eind gekomen aan de lijdensweg die we al sinds 1958 bewandelen, maar laten we niet weer alle ellende oprakelen. We staan aan het eind van een stuk beleid dat gelukkig voorbij is." Iedere hoop op het alsnog in een of andere vorm voortzetten van Rolma noemde hij "absurd", "Op *** koers hebben we naar mijn mening al veel te lang gevaren."

'Nol de Jong, secretary of the works council, said tersely: "An end has come to the path of suffering which we have followed since 1958, but let's not stir up all that misery again. We are standing at the end of a period of management which happily has passed." He said it was "absurd" to hope that Rolma would be continued in some other form. "In my opinion we have followed $* * *$ course much too long already".'

The adjective suggests that Nol de Jong wishes to turn away from and hence decrease attention from the course of action under discussion. It is then not surprising that, when the entire passage was presented, $78 \%$ of the fifty subjects chose die, the demonstrative found in the original text. (Hence, for this example, the difference between identification in context and identification in isolation is $78 \%-46 \%=+32$ percentage points).

\subsubsection{Tense}

We will now consider briefly two sources of information within the sentence which may be expected to influence the subjects' choice of demonstrative in 
the isolated sentences and thereby determine, though indirectly, the magnitude of the context effect. The first of these is verb tense.

One may reasonably expect there to be some interaction between the choice of demonstratives (telling the hearer how much to attend to what entities) and the tense of the finite verb, which situates the event with respect to the time of the speech event. ${ }^{4}$ If it is assumed that the speaker's normal ('unmarked') focus of attention in the speech situation would be the present (the time which he is experiencing directly), one might expect some degree of association between the so-called 'present tense' in Dutch (actually a non-past tense) and the use of deze and, conversely, between the 'past tense' and the use of die. For the 48 test sentences containing deze and the 48 containing die, the observed breakdown is given in Table 7 .

Table 7. Cross-tabulation of tense and demonstrative type in the questionnaire sentences

\begin{tabular}{lllll}
\hline & $\begin{array}{l}\text { Plain } \\
\text { Present }\end{array}$ & $\begin{array}{l}\text { Plain } \\
\text { Past }\end{array}$ & $\begin{array}{l}\text { Perfect } \\
\text { Tenses }\end{array}$ & Total \\
\hline deze & 34 & 9 & 5 & 48 \\
die & 24 & 18 & 6 & 48 \\
\hline
\end{tabular}

Limiting our attention to the 43 deze-sentences and the 42 die-sentences containing non-Perfect verb forms, we see that there is an appreciable skewing: $59 \%$ of 'present tense' verb forms co-occur with deze and $67 \%$ of past verb forms co-occur with die. The odds ratio of $(34 / 24) /(9 / 18)=2.83$ indicates that deze is almost three times as likely to co-occur with the present tense than is die. A chi-square test indicates that this skewing is statistically significant: $\chi^{2}(d f=1)=4.72,(p<.05)$.

Now it should be borne in mind that when a sentence is presented in isolation, without any other context, the effect of possible cues within that sentence is magnified, for they are all that the subjects have to go on. We would therefore expect that in the sentences presented in isolation, past tense forms would tend to favor die-responses and present tense forms would tend to favor deze-responses. However, when the context is added, we might expect some of the influence of tense to be overridden by other factors, such as the referential distance, the degree of detail with which the referent has been described, and so forth. It follows that if we examine the difference between the percentage of correct identifications of demonstratives in the contexted sentences and in the isolated sentences, different values could be 
obtained for the same demonstrative in sentences containing past tense verbs and sentences containing present tense verbs.

More specifically, we would expect this difference to be larger when the original (correct) demonstrative is not the one that would be predicted on the basis of the tense of the finite verb. Thus, we predict that the difference between the percentage of correct identifications in context and in isolation would be greater for deze in past tense sentences than for deze in present tense sentences and that the reverse should tend to hold for die; i.e. that the difference between correct identifications in context and in isolation would be greater for die in present tense sentences than for die in past tense sentences.

We may also expect there to be an asymmetry in the results. One factor which we hypothesized to be capable of 'overriding' the effect of tense in the isolated sentences is referential distance. Presentation of the sentences in context reveals what the referent distance is. Because deze is associated with a longer referential distance than die, we anticipate that the context effect in deze-sentences containing a past finite verb will be appreciably larger than the context effect in die-sentences containing a present finite verb. Accordingly, we may predict that (i) the context effect for deze-sentences with past tense verbs will be greater than the context effect for deze-sentences with present tense verbs, (ii) the context effect for die-sentences with present tense verbs will be greater than the context effect for die-sentences with past tense verbs, and (iii) that the magnitude of (i) will be noticeably larger than (ii). The data are given in Table 8.

Table 8. Mean difference between percent correct identifications in sentences in context and sentences in isolation

\begin{tabular}{llll}
\hline Dem. & Tense & Difference & $\begin{array}{l}\text { Result of } t \text {-test } \\
\text { (one-tailed) }\end{array}$ \\
\hline $\begin{array}{llll}\text { deze } \\
\text { deze }\end{array}$ & $\begin{array}{l}\text { present } \\
\text { past }\end{array}$ & $+2.82 \%(\mathrm{~N}=34)$ & $\begin{array}{l}t(41)=-3.14, \\
p<.002\end{array}$ \\
$\begin{array}{l}\text { die } \\
\text { die }\end{array}$ & present & $+20.00 \%:(\mathrm{N}=9)$ & $t(37)=1.09$, \\
& past & $-3.33 \%(\mathrm{~N}=18)$ & $p<.15$ \\
\hline
\end{tabular}

The data accord with all three predictions; note that the difference between deze + past and deze + present is statistically significant, while the difference between die + present and die + past is not. 
A good illustration of the effect of tense is provided by the following example in the past tense:

Toen onder $* * *$ omstandigheden het weer verruwde werd besloten naar de basis terug te keren.

'When under $* * *$ circumstances the weather became rough, it was decided to return to base.'

When this sentence was offered in isolation, $82 \%$ of the subjects chose die as the correct demonstrative. Consider now the full passage:

Omstreeks 21.00 uur geraakte de hydraulische stuurinrichting defect. Hierna werd gestuurd met het handroer op de achtersteven waar een matroos in verbinding stond met de brug door middel van een touw aan zijn polsen gebonden. Omstreeks 21.30 geraakte de scheepstelefoon defect. Toen onder *** omstandigheden het weer verruwde werd besloten naar de basis terug te keren.

'At approximately 21.00 hours the hydraulic steering mechanism broke down. After this, we steered with the hand wheel on the stern, where a sailor was in communication with the bridge by means of a rope tied to his wrists. At approximately 21.30 hours the ship's telephone broke down. When under *** circumstances the weather became rough, it was decided to return to base.'

Note that the detail provided about the circumstances makes them more likely to be regarded as important, worthy of attention, and this overrides to some extent any 'attraction' of die by the past tense. When the entire passage was presented, $56 \%$ of the subjects chose deze, which was in fact the original demonstrative in the corpus. The difference between the percentage of correct identifications in the contexted sentence and in the isolated sentence is accordingly $56 \%-18 \%=+38$ percentage points.

\subsubsection{The role of lexicon}

The second source of information within the sentence which we shall consider is lexicon. Here we encounter a more decisive factor, one less likely to be overriden by the larger context, than something as 'abstract' as tense.

For example, if some lexical item in the sentence suggests that one is confronting spoken rather than written Dutch, then the best choice of demonstrative is die, for as is shown by the written data in the Uit den Boogaart 
(1975) and the Renkema (1981) corpora (5372 demonstratives) and the spoken data in De Jong (1979) (1498 demonstratives), deze is about 12 times less frequent in the spoken than in the written language. Only about $5 \%$ of demonstratives in the spoken sample are deze, compared with about $60 \%$ in the total written sample (all corpora).

One such lexical item is nou 'now, well', historically a variant of $n u$ 'now'. According to the data in Uit den Boogaart (1975) and De Jong (1979), one occurrence of nou is found in written Dutch every 2500 words or so (on the average), but in spoken Dutch in about every 190 words (on the average). $\mathrm{Nou}$ is thus about thirteen times more frequent in the spoken language than the written. We therefore expect that subjects encountering a nou in the isolated sentences would confidently select die as the most likely demonstrative, and this is indeed what we find:

Nou, dan moet je ${ }^{* * *}$ kampioenen well zichtbaar maken en een naam geven.

'Well, in that case you must make ${ }^{* * *}$ champions visible and give them a name.'

Faced with this sentence in isolation, $98 \%$ of the 50 subjects correctly chose die; when it was presented in context, $100 \%$ of the subjects chose die.

In some cases, the very noun co-occurring with the demonstrative indicates that the language is spoken Dutch. Pejoratives are a good example:

Als $* * *$ ellendige trut er niet tussen gekomen was, dan was ik nu met Fred getrouwd.

'If *** wretched female had not come in between, I would now be married to Fred.'

Trut is classified in the latest edition of the authoritative Van Dale dictionary (Geerts, Heestermans and Kruyskamp, 1984) as a pejorative term for 'woman'. It is therefore not at all surprising that $100 \%$ of the subjects chose die in the sentence presented in isolation, which was the correct form.

Examples such as these suggest that the strong association of die with spoken Dutch is a second factor (in addition to die's smaller average referent distance) accounting for the lack of any appreciable overall context effect with die as opposed to deze (cf. Figure 2). If a sentence can be identified purely on the basis of its lexicon as colloquial Dutch, then die is in fact the 
most likely demonstrative and (as we have seen) there will be little improvement' in the subjects' choice when the rest of the context is added.

\section{Summary and conclusions.}

This paper has presented initial data from an exploratory questionnaire experiment on factors influencing native speakers' choice of demonstrative adjectives in written Dutch sentences presented both in isolation and in context.

The first such factor is 'genre', here described more accurately and operationally as simply text-type. The results suggest first of all that native speakers have internalized to some degree the relative frequency of the two kinds of demonstratives in different texts, at least at the two extremes of overwhelmingly die versus overwhelmingly deze. Novels, being largely colloquial, are expected to contain few instances of deze; government language, typically regarded as legalese, is expected to contain few instances of die. To the extent that native speakers recognize these text-types, they choose the stereotyped form.

The second factor is referential distance, here measured as the number of sentence boundaries one must cross to go from the mention of the referent effected with the demonstrative-bearing NP back to its first prior mention in the discourse. The fact that deze has a larger average RD than die explains the observation that - on the whole - the number of correct identifications of original deze increases in context (when previous sentences are added), while the number of correct identifications of die does not. The importance of RD is also shown by examination of misidentifications in the contexted sentences. When each sentence is used as its own control, one discovers that original dies with relatively long RDs tend to get erroneously classified as deze.

A third factor influencing demonstrative choice is the presence of additional information in the context about either the referent itself or the speaker's attitude towards it. Entities which are 'developed' in the context, which are discussed in detail, or which continue to be viewed as topical are referred to with NPs receiving deze.

A fourth influence is the tense of the main verb in the test sentences. Everything else being equal, present tense would tend to attract deze and past tense die. But the influence of tense in isolated sentences can be 'overridden' by context factors two and three, above. 
The last factor discussed was lexicon. The examples suggest that what it does is simply help the native speaker recognize the text-type (at least at the extremes mentioned above), so that demonstrative choice then proceeds via the 'stereotyping' route already described in the first paragraph.

On the whole, the responses of the 50 subjects to the identification task complement the results of the text-studies mentioned in Section 1. One might suggest that the same explanation holds for both, in the sense that both the experimental subjects and the authors of texts choose that demonstrative whose meaning is least inappropriate to the particular messages they are engaged in communicating. The association of deze with a long referential distance, with greater detail provided about the referent, and with the referent's continued topicality and the association of die with precisely the opposite lends credence to a view of deze - at least in its discourse exploitation as instructing the addressee more forcefully than die to seek out and attend to the noun's referent. ${ }^{5}$

Finally, it will be recognized that the present paper raises a number of questions, not only about the Dutch demonstratives but also about the texts from which the test sentences were taken. Ideally one would want to know whether the trend towards an increasing use of deze seen in Table 1 is independent of verb tense in the subcorpora. If not, then the explanation for the 'text effect' may need revision. Also, why does the referential distance associated with deze and die vary in the particular way it does across the subcorpora in Table 2? Why is there a significant difference in the RD associated with the demonstrative only in opinion and analysis, popular science, and government but not in daily newspapers, and is this true for larger samples from the subcorpora than were used in the questionnaire? It is perhaps only to be expected that an experiment based on the actual use of demonstratives in real texts would highlight our ignorance of not only the former but of the latter as well.

\section{Notes}

* The research reported on in this paper was carried out in part while the first author was a Fellow in Residence and a Visiting Scholar at the Netherlands Institute for Advanced Study in the Humanities and Social Sciences at Wassenaar, Holland. The first author wishes to acknowledge support from National Science Foundation Grant BNS-7923447 to the University of California, Los Angeles; any opinions, findings, and conclusions are those of the authors and do not necessarily reflect the 
views of the National Science Foundation. This research was also supported by Grant 2964 from the Academic Senate of the University of California, Los Angeles. In addition, the authors would like to thank ir. G. van der Steen, Computer Division, Faculty of Letters, University of Amsterdam for his assistance in obtaining the data, as well as dr. J. Renkema, Katholieke Universiteit Brabant, for making his material available to us. Finally, the authors would like to thank the editor and the anonymous referees of Text for their critical comments on an earlier version of this paper.

1. One of the anonymous referees has pointed out that subcorpus 6 , government language, may also be viewed as containing diverse genres. For details, the reader is referred to Renkema (1981).

2. For introductory explanations of the statistics used in this study (namely, the nonparametric chi-square test cited here, plus the $t$-test, the Mann Whitney U test, the Pearson correlation coefficient $r$, the phi coefficient, and the odds ratio), the reader is referred to Butler (1985), Miller (1975), Nie et al. (1975), Phillips (1973), Reynolds (1979), and Siegel (1956). The Miller and Siegel texts contain clear discussions of the differences between parametric and non-parametric (i.e. 'distribution-free') tests, one-tailed and two-tailed probability estimates, and the distinctions between nominal, ordinal, interval, and ratio scaling of data.

3. We should perhaps stress the word tend here, since it is clear that both deze and die can be used for both intrasentential and extrasentential 'retrieval' of a referent. In other words, both demonstratives can contribute to the cohesion of a text, in the sense of Van Dijk $(1978,1980)$, Halliday and Hasan (1976), and Widdowson (1978). But the point of the present study is to explore the differences between the kind of cohesion effected with deze and the kind effected with die. See further the discussion in Section 5.2.2.

4. We wish to thank Saskia Daalder of the Free University, Amsterdam, for discussion of this point.

5. For some discussion of different approaches to the semantic analysis of the Dutch demonstrative adjectives, see Kirsner and van Heuven (1986), Section 7. $\dot{2}$.

\section{References}

Buchler, Justus (ed.) (1940). The Philosophy of Pierce: Selected Writings. New York: Harcourt, Brace, and Company.

Butler, Christopher (1985). Statistics in Linguistics. Oxford: Basil Blackwell.

Dijk, Teun van (1978). Tekstwetenschap: Een Interdisciplinaire Inleiding. Utrecht: Het Spectrum.

- (1980). Macrostructures: An Interdisciplinary Study of Global Structures in Discourse, Interaction, and Cognition. Hillsdale, N.J.: Lawrence Erlbaum.

Geerts, G. and Heestermans, H., with the collaboration of C. Kruyskamp (1984). Van Dale. Groot Woordenboek der Nederlandse Taal, 3 vols. Utrecht: Van Dale Lexicografie.

Givón, T. (ed.) (1983). Topic Continuity in Discourse: A Quantitative Cross-Language Study. Amsterdam: John Benjamins.

Grosjean, F. (1980). Spoken word recognition processes and the gating paradigm. Perception and Psychophysics 28: 267-283.

Halliday, M.A.K. and Hasan, Ruqaiya (1976). Cohesion in English. London: Longman. 
Heuven, Vincent van (1978). Spelling en Lezen. Hoe Tragisch zijn de Werkwoordsvormen? Assen: Van Gorcum.

Jakobson, Roman. (1971). Language in relation to other communication systems. In his Selected Writings, 2.697-2.708. Mouton: The Hague.

Jarvella, Robert J. and Klein, Wolfgang (eds.) (1982). Speech, Place, and Action: Studies in Deix is and Related Topics. Chichester: Wiley.

Jong, Eveline D. de (1979). Spreektaal: Woordfrequenties in Gesproken Nederlands. Utrecht: Bohn, Scheltema and Holkema.

Kirsner, Robert S. (1979). Deixis in discourse: an exploratory quantitative study of the Modern Dutch demonstrative adjectives. In Syntax and Semantics 12: Discourse and Syntax, T. Givón (ed.), 355-375. New York: Academic Press.

- (1985). Quantitative approaches to Dutch linguistic structure. In Papers from the First Interdisciplinary Conference on Netherlandic Studies: University of Maryland, June 1982, William H. Fletcher (ed.), 95-104. New York: University Press of America.

- (1987). What it takes to show whether an analysis 'fits'. In Descriptio Linguistica: Proceedings of the First Conference on Descriptive and Structural Linguistics, Antwerp 9-10 September 1985, Hermann Bluhme and Göran Hammarström (eds.) 79-116. Tübingen: Gunter Narr.

Kirsner, Robert S. and Heuven, Vincent J. van (1980). On the opposition between deze (dit) and die (dat) in written Dutch: a discriminant analysis. In Linguistics in The Netherlands 1980, Saskia Daalder and Marinel Gerritsen, (eds.), 102-109. Amsterdam: North-Holland.

-, - (1986). The Modern Dutch demonstrative adjectives: intrasentential position and discourse function. Manuscript.

Miller, Steve (1975). Experimental Design and Statistics. London: Methuen.

Nie, Norman H. et al. (1975). SPSS: Statistical Package for the Social Sciences. New York: McGraw-Hill.

Nuchelmans, G. (1969). Overzicht van de Analytische Wijsbegeerte. Utrecht: Het Spectrum.

Phillips, John L., Jr. (1973). Statistical Thinking: A Structural Approach. San Francisco: W.H. Freeman.

Renkema, J. (1981). De Taal van 'Den Haag': Een Kwantitatief-Stilistisch Onderzoek naar Aanleiding van Oordelen over Taalgebruik. Den Haag: Staatsuitgeverij.

Reynolds, H.T. (1979). The Analysis of Nominal Data. Sage University Paper Series on Quantitative Applications in the Social Sciences 07-007. Beverly Hills and London: Sage.

Siegel, Sidney (1956). Nonparametric Statistics for the Behavioral Sciences. New York: McGraw-Hill.

Steen, Gert J. van der (1982). A treatment of queries in large text corpora. In Computer Corpora in English Language Research, S. Johansson (ed.), 49-65. Bergen: Norwegian Computing Centre for the Humanities.

Uit den Boogaart, P.C. (ed.) (1975). Woordfrequenties in Geschreven en Gesproken Nederlands. Utrecht: Oosthoek, Scheltema and Holkema.

Wiessenborn, Jürgen and Klein, Wolfgang (eds.) (1982). Here and There: Cross-linguistic Studies on Deixis and Demonstration. (Pragmatics and Beyond III: 2/3) Amsterdam: John Benjamins.

Widdowson, H.G. (1978). Teaching Language as Communication. Oxford: Oxford University Press. 
Robert S. Kirsner is Associate Professor of Dutch and Afrikaans at the University of California, Los Angeles, with research interests in the semantics and pragmatics of grammatical systems. His publications include The Problem of Presentative Sentences in Modern Dutch (1979), 'On the use of quantitative discourse data to determine inferential mechanisms in grammar', in F. Klein (ed.) Discourse Perspectives on Syntax (1983), and 'On being empirical with indirect objects: the subtleties of aan', in $J$. van Oosten and J. Snapper (eds.) Dutch Linguistics at Berkeley: Proceedings of a Colloquium (1986).

Vincent J. van Heuven is Associate Professor of Phonetics at Leyden University, with a special interest in experimental linguistics and phonetics. His publications include a book on psycholinguistic aspects of Dutch spelling reform and various articles, including 'Auditory discrimination of rise and decay times in tone and noise bursts', Journal of the Acoustical Society of America 66 (1979), and 'Some acoustic characteristics and perceptual consequences of foreign accent in Dutch spoken by Turkish immigrant workers', in J. van Oosten and J. Snapper (eds.) Dutch Linguistics at Berkeley: Proceedings of a Colloquium (1986).

Jos F.M. Vermeulen was a student in the Department of Dutch language and literature at Leyden University. He is now employed as a computer programmer by Transmark B.V., Amsterdam. 